\title{
Hepatitis B vaccination in Nepalese infants: The present scenario
}

\section{Sudhir Adhikari' ${ }^{1}$, Brijesh Sathian ${ }^{2}$}

Correspondence: Dr. Sudhir Adhikari, Assistant Professor, Department of Pediatrics, Manipal College of

Medical Sciences, Pokhara, Nepal.

Email: sudhiradhikari99@gmail.com

Received 11 September 2017/Revised 25 September 2017/Accepted 29 September 2017

Citation: Adhikari S, Sathian B. Hepatitis B vaccination in Nepalese infants: The present scenario. Nepal J

Epidemiol. 2017;7(3); 694-696.

DOI: $10.3126 /$ nje.v7i3.19007

This work is licensed under a Creative Commons Attribution 4.0 International License.

\section{Copyright @ 2017 CEA\& INEA. Published online by NepJOL-INASP. www.nepjol.info/index.php/NJE}

According to the latest WHO 2015 estimation, 257 million people were infected with hepatitis $B$ virus and a mortality of 887000 (because of associated hepatocellular carcinoma and cirrhosis). In addition, prevalence of Hepatitis B in WHO South-East Asia Region was $2.0 \%$ [1]. Infections acquired during infancy and young age carry a high risk of evolution into chronic HBsAg carrier stage.

Preventive strategies along with Hepatitis $\mathrm{B}$ vaccine have a great impact to reduce the incidence of new infections over last few decades. Passive immunization with hepatitis B immune globulin (HBIG) and active immunization with Hepatitis B vaccine has resulted in a sudden decline in the disease incidence. Immunization of infants significantly reduces the incidence of vertical transmission of the virus from the affected mothers. This is probably the most effective health intervention.

The government of Nepal along with the aid of GAVI had introduced Hepatitis B vaccine in phase-wise manner from 2002 to 2004. It is currently administered as penta-valent vaccine along with Hemophilus influenza $\mathrm{B}(\mathrm{HiB})$ and Diphtheria Pertussis and Tetanus(DPT) vaccines at 6, 10 and 14 weeks of age [2]. Infants those who are born from hepatitis B surface antigen ( $\mathrm{HBsAg}$ ) negative mothers can effectively be protected from the hepatitis B viral infections by good immunization coverage.

However, infants born with HBsAg positive mothers need national strategies for active as well as passive immunization. Hepatitis B vaccine is recommended within 24 hours of life by the American academy of pediatrics (AAP). Additional 0.5 $\mathrm{mL}$ of HBIG within 12 hours of birth is indicated for infants of mothers with HBsAg+ or unknown HBsAg status [3]. HBIG should be administered within 72 hours for maximum benefit but not useful beyond 7 days. HBsAg antibody titres should be done at age 9 to 12 months or 1 to 2 months after completion of the HepB vaccination [3]. A systematic review done by Machaira et al reported that the effectiveness of vaccine alone compared with vaccine plus HBIG for the immunization of babies of $\mathrm{HBsAg}+/ \mathrm{HBeAg}$ - mothers were equal [4].

In 2012, Upreti et al had reported a low burden of chronic hepatitis $\mathrm{B}$ viral infection among children born in both the $\operatorname{pre}(0.28 \%)$ and the post-vaccination (0.13\%) era [5]. However, another study carried out in a remote District of Western Nepal in the year 2014 had shown high burden of hepatitis $\mathrm{B}$ infections in mothers and children younger than 5 years [6]. This raises the concern that $\mathrm{HBs} A g$ carrier rates can 
be higher than the national projection in marginalized and rural population.

There are few concerns about effective prevention of hepatitis B viral infection strategies at birth. A significant number of mothers do not have antenatal visit and home delivery is also common. There is lack of policy for administration of HBIG along with a birth dose of HBsAg vaccine to newborns born from $\mathrm{HBsAg}$ positive mothers. Regular availability of $\mathrm{HBIG}$ and $\mathrm{HBsAg}$ vaccine is another concern. Passive immunization also has additional financial burden on the families.

In the National Immunization Schedule (NIS) the Pentavalent vaccine (DPT, HiB and Hepatitis B) is given at 6, 10 and 14 weeks. There is a dilemma how to incorporate infants who receive birth dose of hepatitis $B$ vaccine in this schedule. There is also lack of antibody titre measurement against HBsAg and follow up of these high-risk infants. A populationbased study from southern Nepal had shown that though national coverage of routine immunization is reported to be high there is also a concern for delay and incomplete receipt of vaccines under NIS [7].

Nepal has achieved a great progress in childhood immunization over decades. Health promotion and prevention has maintained the transmission of hepatitis $\mathrm{B}$ to a low rate in Nepal. But only 21 out of 75 districts in Nepal have achieved more than 90\% DPT-Hep-Hib3 coverage in 2016 [8]. There is a noticeable $10 \%$ reduction in coverage from 2014 (92\%) to $2016(81 \%)$ of DPT-Hep-Hib3 [8]. In addition, DPT-HepBHib vaccine wastage rate was greater than the accepted rate of $15 \%$ [8]. Under the sustainable Development Agenda 2030, WHO is supporting the countries for achieving the global hepatitis goals by formulating evidence-based policy and data for action, promoting partnerships and mobilizing resources, raising awareness, preventing transmission, and also improving the screening, care and treatment services [1]. There is an urgent need for a national policy for active and passive hepatitis $\mathrm{B}$ immunization to sustain our low transmission status.

\section{Abbreviations \\ AAP- American academy of pediatrics \\ DPT- Diphtheria Pertussis and Tetanus \\ HBIG- hepatitis B immune globulin \\ $\mathrm{HBsAg-hepatitis} \mathrm{B} \mathrm{surface} \mathrm{antigen}$ \\ HiB- Hemophilus influenza B \\ NIS- National immunization schedule}

\section{Conflict of interest:}

The authors declared no potential conflicts of interest with respect to the research, authorship, and/or publication of this article.
Funding:

The authors received no financial support for the authorship, and/or publication of this article.

Author's affiliations:

${ }^{1}$ Assistant Professor, Department of Pediatrics, Manipal College of Medical Sciences, Pokhara, Nepal.

${ }^{2}$ Academic Research Associate, Trauma Surgery Hamad General Hospital, P. O BOX 3050, Doha, Qatar

\section{References:}

1. WHO. Hepatitis B. [online] 2017 [cited 2017 May 23]. Available from: http://www.who.int/mediacentre/ factsheets/ fs204/en/

2. Ministry of Health and Population. National Immunization Program. Reaching Every Child. National Immunization Program. Comprehensive Multi-Year Plan 2068-2072 (20112016). [online] 2011 [cited 2017 May 1]. Available from: http://dohs.gov.np/wp-content/uploads/chd/ Immunization/ cMYP_2012_2016_May_2011.pdf

3. CDC. Recommended Immunization Schedule for Children and Adolescents Aged 18 Years or Younger, United States. [online] 2017 [cited 2017 May 23]. Available from: https://www.aap.org/en- us/Documents/

immunizationschedule2017.pdf

4. Machaira M, Papaevangelou V, Vouloumanou EK, Tansarli GS, Falagas ME. Hepatitis B vaccine alone or with hepatitis B immunoglobulin in neonates of $\mathrm{HBs} \mathrm{Ag}+/ \mathrm{HBeAg}$ - mothers: a systematic review and meta-analysis. J Antimicrob Chemother.2015 Feb;70(2):396-404.

\section{https://doi.org/10.1093/jac/dku404}

PMid: 25362571

5. Upreti SR, Gurung S, Patel M, Dixit SM, Krause LK, Shakya G, Wannemuehler K, Rajbhandari R, Bohara R, Schluter WW. Prevalence of chronic hepatitis B virus infection before and after implementation of a hepatitis B vaccination program among children in Nepal. Vaccine. 2014;32(34):4304-9.

https://doi.org/10.1016/j.vaccine.2014.06.027

PMid: 24951865

6. Shedain PR, Devkota MD, Banjara MR, Ling H, Dhital S. Prevalence and risk factors of hepatitis $\mathrm{B}$ infection among mothers and children with hepatitis B infected mother in upper Dolpa, Nepal. BMC Infect Dis. 2017 Oct 10;17(1):667.

https://doi.org/10.1186/s12879-017-2763-4

PMCid: PMC5633872

7. Hughes MM, Katz J, Englund JA, Khatry SK, Shrestha L, LeClerq SC, Steinhoff M, Tielsch JM. Infant vaccination timing: Beyond traditional coverage metrics for maximizing impact of vaccine programs, an example from southern Nepal. Vaccine. 2016;34(7):933-41. 
https://doi.org/10.1016/j.vaccine.2015.12.061

PMid:26788880 PMCid:PMC4744084

8. Ministry of Health. Child Health. Annual Report 2017. [online] 2017 [cited 2017 May 23]. Available from: http://dohs.gov.np/wp-content/uploads/2017/06/

DoHS_Annual_Report_2072_73.pdf 